\title{
Inheritance: How Our Genes Change Our Lives_and Our Lives Change Our Genes
}

\author{
by Sharon Moalem \\ New York: Grand Central Publishing, 2014 \\ ISBN 978-1-4555-4944-3 \\ Hardcover \$19.53, 225 pp.
}

\section{Reviewed by Andy Céline Martin \\ University of Regina}

The author of Inheritance: How Our Genes Change Our Lives-and Our Lives Change Our Genes, Dr. Sharon Moalem, assures us that by the end of his book, or even by the end of this article, your entire genome, and the life it has helped to shape, will never look or feel the same. Conventional wisdom dictates that our genetic destiny is fixed at conception, but Moalem's groundbreaking book shows us that the human genome is far more fluid and fascinating than most doctors and scientists ever imagined-that our genes are more a shifting tide than a crystal ball. For better or worse, science is discovering that it is possible to accept or reject our inheritance.

This acceptance and rejection is mediated and orchestrated by how you live, where you live, the stresses you face, and the things you consume; all these things can be changed. Consequently, in very certain terms, this means that you can change, genetically. Science is coming to better understand the relationship between what our genes do to us and what we do to our genes. Everything-food, exercise, relationships, medication, education, and laws - can change us genetically. Whether you are seated at your desk typing away on a computer, collapsed into a recliner sipping a coffee, or jogging on a treadmill at the gym, your DNA is constantly being modified. Like thousands of little light switches, some are turning on while others are turning off, all in response to what you're doing, what you're seeing, and what you're feeling. The book Inheritance: How Our Genes Change Our Livesand Our Lives Change Our Genes is a compendium for that journey.

To help readers wrap their minds around this groundbreaking information, Moalem eloquently illustrates the flexibility of our inherited DNA through bees—-specifically, queen bees. Most people know how drastically queen bees differ from other bees: they're more slender and smooth, have longer bodies and legs, and have stingers that can be reused on demand, unlike worker bees who die after using their stingers just once. Queen bees can also lay thousands of eggs a day and can live for many years, while workers bees' lives span mere weeks.

Given these facts, it's easy to assume that queens differ genetically from the workers. Yet, in truth, genetically speaking, the queen is nobody special. A queen bee and her workers can actually come from the same parents and can have completely identical DNA. Nonetheless, queen bees and worker bees differ profoundly, which, as Moalem reports, is merely because queen bees eat better. When the colony decides it's time for a new queen, they choose a few lucky larvae and bathe them in royal jelly (a protein- and amino acid-rich secretion produced by glands in the mouths of young worker bees), which they eat and eat until one bee murders all of the rest and gets to be queen. The food the queen eats changes her genetic expression: certain genes, like little light switches, are being turned on or off because of this royal jelly. The queen bee's genes are no different, but her genetic expression is. Therefore, two bees can have the same genes; yet, depending on the instructions given to those genes (i.e., turning certain genes on or off), they can be expressed differently.

Why is this important to us? For starters, like every other creature on this planet, bees share a lot of genetic sequences with us. Our diet differs from that of bees, of course, but they have given us many amazing examples of how our genes express themselves to meet the demands of our lives. And just like bees, our lives can be mo- 
mentously impacted by genetic expression. While avoiding getting bogged down in unnecessary details, Moalem explains to the reader how genetic traits can change- that genes are surprisingly sensitive, and how we live influences our DNA. The interplay between genes and our experiences, environment, and diet creates a unique genetic expression that is flexible, not fixed. This means that genes can carry trauma and disease from one generation to the next-but it also means genes can be influenced to change. Moalem masterfully documents how, although scientists have isolated genes responsible for certain conditions (e.g., diabetes, hypertension), the factors that give rise to these conditions is a complicated and tangled web that likely involves more than one gene as well as many unique experiences.

To date, most of us haven't yet realized the extent to which our genes remain flexible. Drawing on cutting-edge science, and also on the heart-breaking and heart-warming stories of individuals he has treated for rare genetic anomalies, Moalem explains how our DNA is constantly shape-shifting. Human beings are more than the product of a genetic blueprint. As Moalem writes, "We are the genetic culmination of our life experiences, as well as every event our parents and ancestors ever lived through and survived" (p. 58). Thus, our genetic strength isn't just a matter of receiving the genes handed down to us from previous generations, but includes the opportunity to transform what we get and what we give. What we know now is that even for those who have a "perfect genetic inheritance," disuse, old age, poor diets, and hormonal changes can all wreak havoc on this genetic structure. Correspondingly, in the nature v. nurture tug-of-war, there is no clear-cut winner.

Inheritance: How Our Genes Change Our Lives — and Our Lives Change Our Genes is a groundbreaking magnum opus that transforms how we understand ourselves and our families, by revealing that everything we thought we knew about genetics isn't necessarily the case. This book isn't exclusively accessible for those in the medical field, but rather is of great relevance to the general public, or those who find medical anomalies interesting. In fact, Moalem references a wide array of subjects to illustrate his points, such as history, art, superheroes, sports stars, and sex workers. Further, the connection he makes between all of these subjects changes the way we look at the world, and even the way we look at ourselves. This book will make you think about the way you live; about how, genetically speaking, you got to this very moment in your life. Moalem's message is ultimately one of empowerment: we're accelerating into a world where understanding our unique genetic inheritance will give us the power to eat, exercise, and seek medical treatment tailored to what our body really needs, altering the course of what was once understood as a fixed path. No longer do we have to settle for what we've been given; at any time, we can start turning lights on or off, and write our own story. 